\title{
Integrated production of an influenza A vaccine candidate with MDCK suspension cells
}

\author{
Thomas Bissinger ${ }^{1}$, Yixiao $\mathrm{Wu}^{1}$, Pavel Marichal-Gallardo ${ }^{1}$, Dietmar Riedel ${ }^{2}, \mathrm{Xuping} \mathrm{Liu}^{3}$, \\ Y Genzel ${ }^{1}$, wen Tan $^{3}$, and Udo Reichl ${ }^{1}$
}

${ }^{1}$ Max Planck Institute for Dynamics of Complex Technical Systems

${ }^{2}$ Max Planck Institute for Biophysical Chemistry

${ }^{3}$ East China University of Science and Technology

March 3, 2021

\begin{abstract}
Seasonal influenza infection waves occur both in northern and southern hemispheres every year. Despite the differences in influenza virus surface antigens and virulence of seasonal subtypes, manufacturers are well-adapted to respond to this periodical vaccine demand. Due to decades of influenza virus research, the development of new influenza vaccines is relatively straightforward. Nevertheless, compared to the recent Covid-19 pandemic where a vaccine is not yet available, influenza vaccine manufacturing would be a major bottleneck for the rapid supply of billions of doses required worldwide. In particular, eggbased vaccine production would be difficult to schedule and shortages of other egg-based vaccines with high demands also have to be anticipated. Cell culture-based production systems enable manufacturing of large amounts of vaccines within a short time frame and expand significantly our options to respond to pandemics and emerging viral diseases. In this work, we present an integrated process for the production of inactivated influenza A virus vaccines based on a MDCK suspension cell line cultivated in a chemically defined medium. Very high titers of $3.6 \log 10(\mathrm{HAU} / 100 \mu \mathrm{L})$ were achieved using fast growing MDCK cells at concentrations up to $9.5 \times 106$ cells $/ \mathrm{mL}$ infected with influenza $\mathrm{A} / \mathrm{PR} / 8 / 34 \mathrm{H} 1 \mathrm{~N} 1$ virus in $1 \mathrm{~L}$ stirred tank bioreactors. A combination of two membrane-based chromatography steps enabled full recovery for the virus capture and up to $80 \%$ recovery for the virus polishing step, respectively. Purified virus particles showed a homogenous size distribution around a mean diameter of $80 \mathrm{~nm}$. Based on a monovalent dose of $15 \mu \mathrm{g}$ hemagglutinin (SRID assay), the level of total protein was $58 \mu \mathrm{g}$ and the level of host cell DNA contamination was below $10 \mathrm{ng}$. Furthermore, all process steps can be fully scaled up to industrial quantities for commercial manufacturing of either seasonal or pandemic influenza virus vaccines. Fast production of up to 300 vaccine doses per liter within 4 to 5 days makes this process competitive not only to other cell-based processes, but to egg-based processes as well.
\end{abstract}

\section{Hosted file}

Manuscript_USP_DSP_IAV_submission_02.pdf available at https://authorea.com/users/399241/ articles/511801-integrated-production-of-an-influenza-a-vaccine-candidate-with-mdcksuspension-cells 

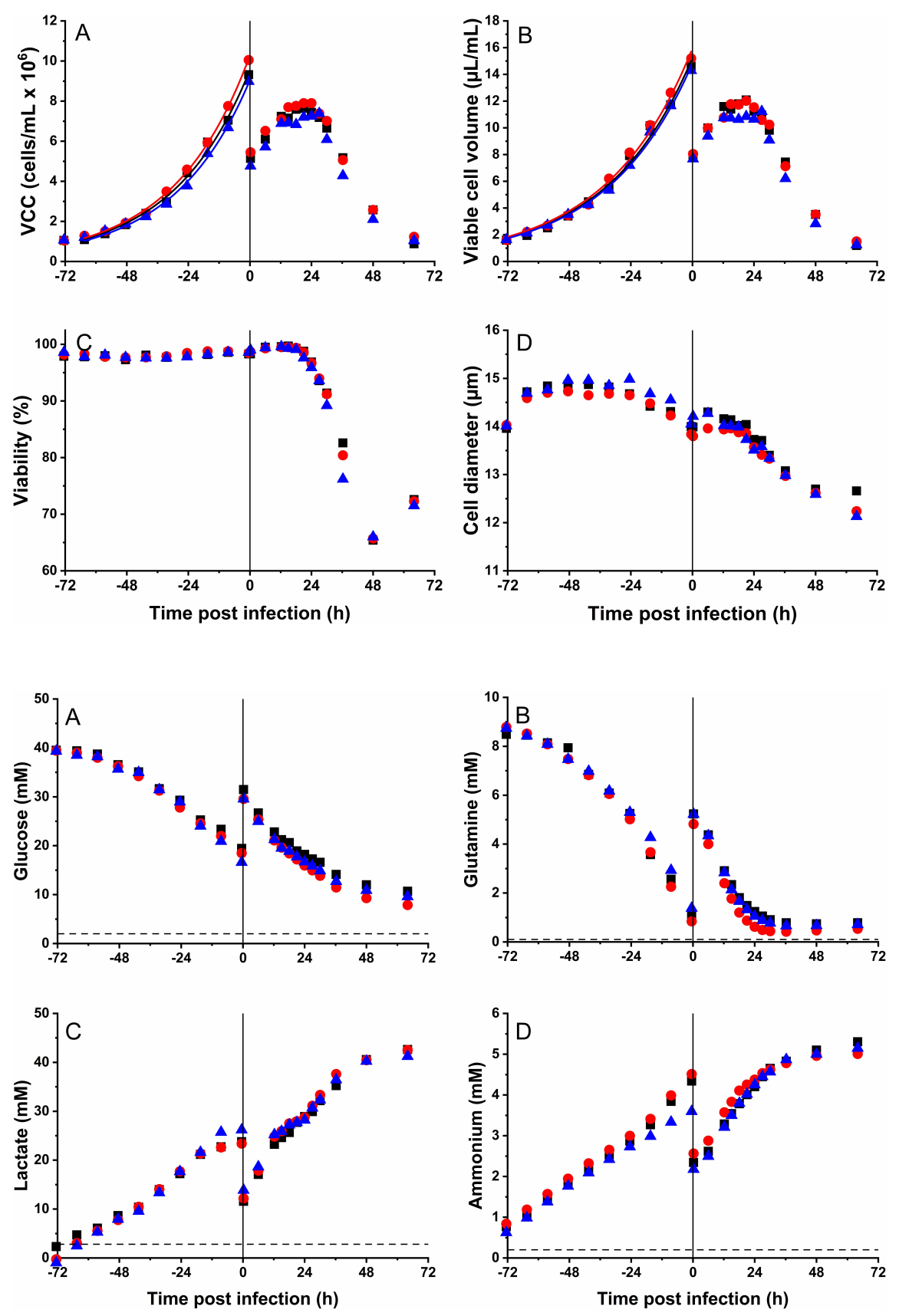

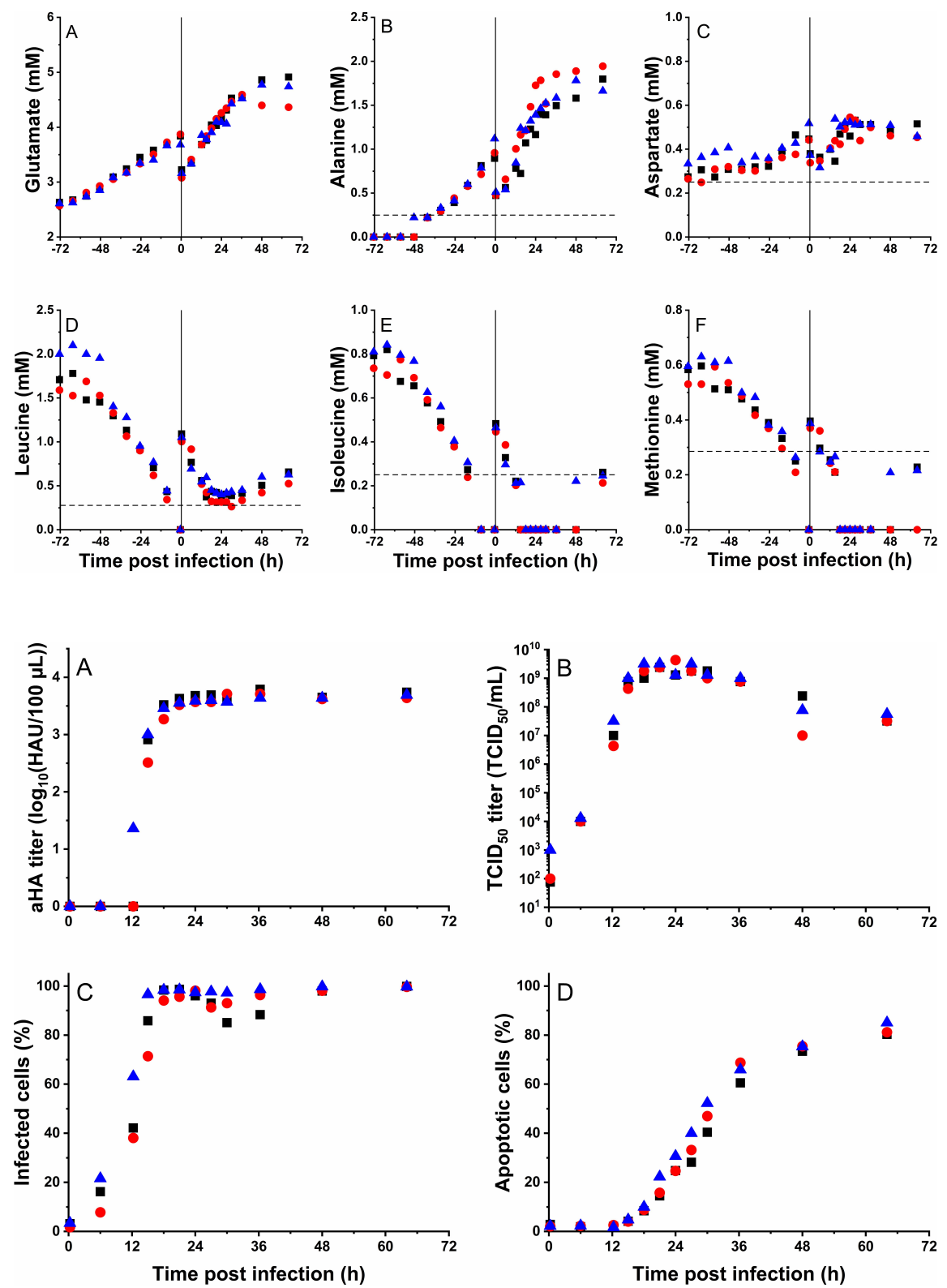

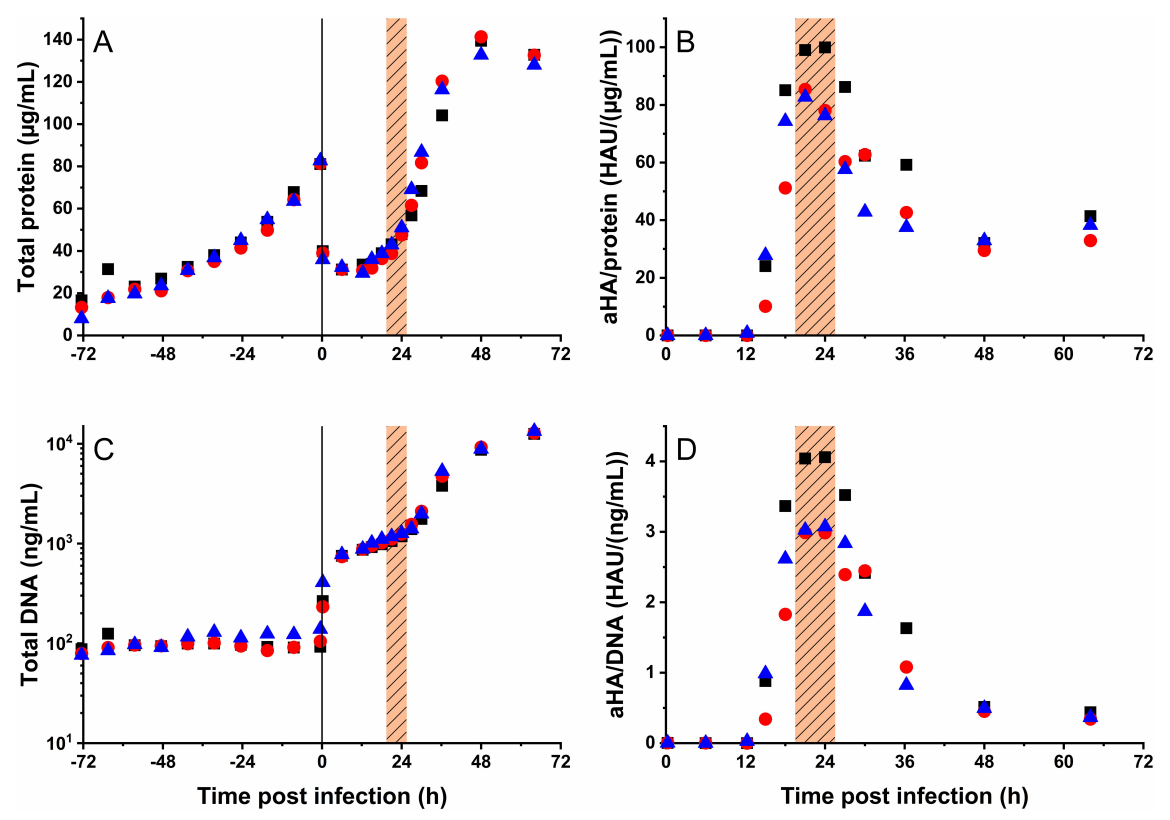

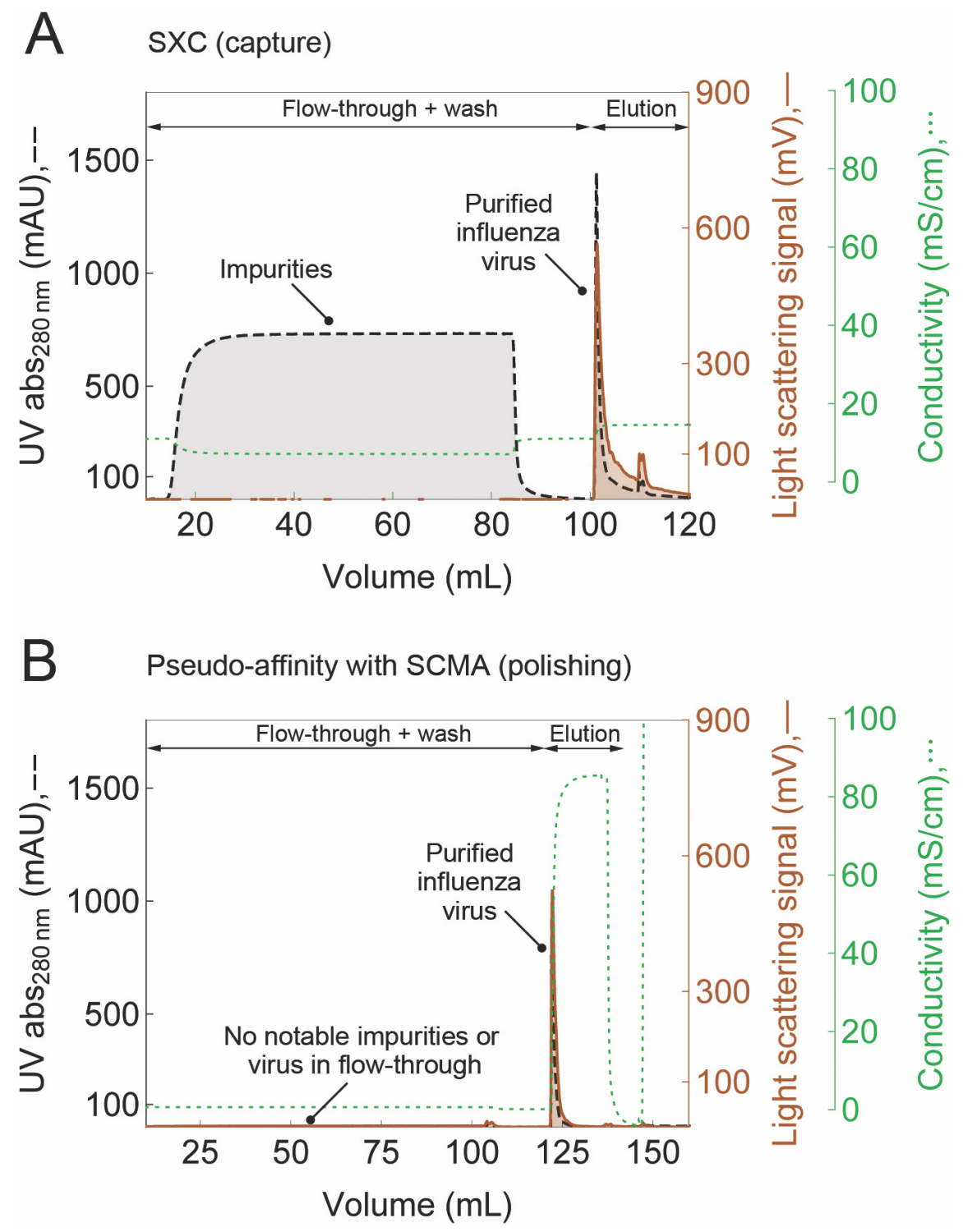

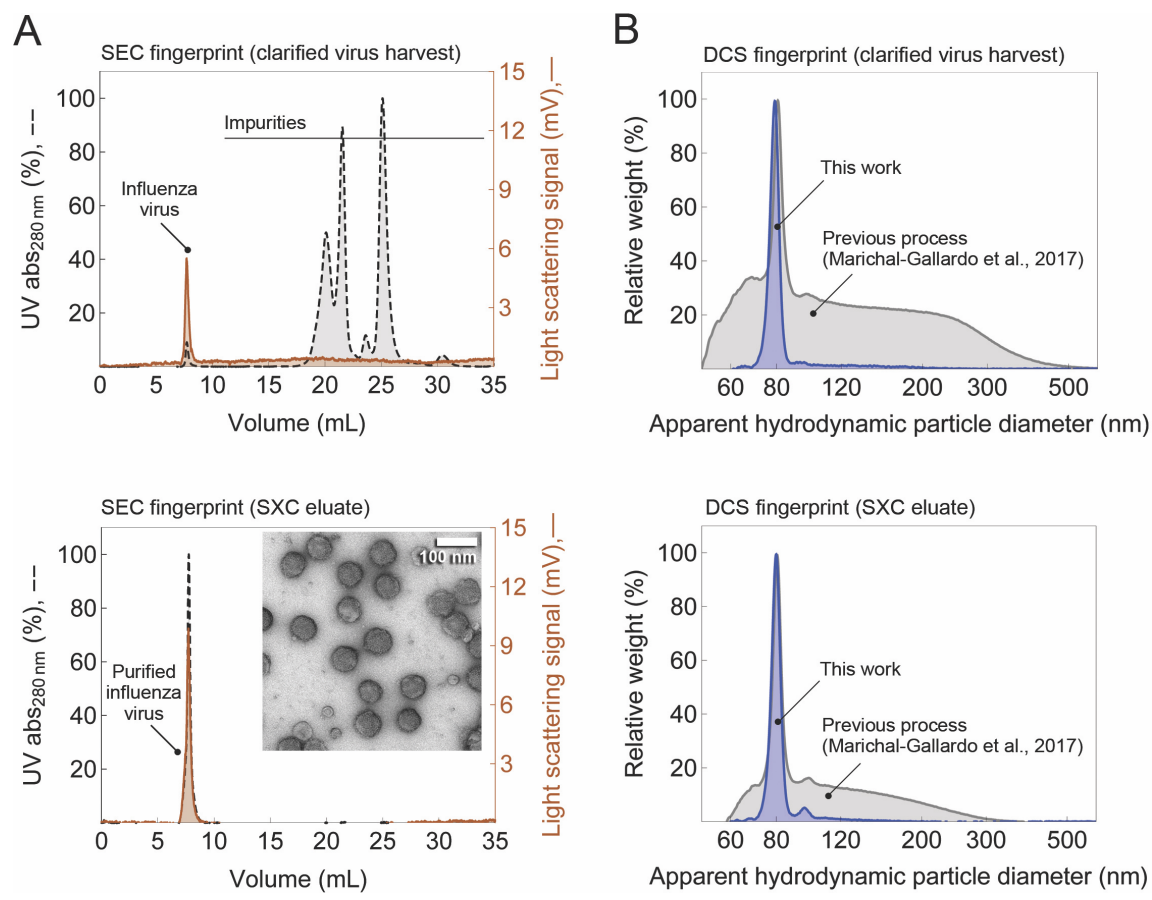

\section{Hosted file}

Table_01.pdf available at https://authorea.com/users/399241/articles/511801-integratedproduction-of-an-influenza-a-vaccine-candidate-with-mdck-suspension-cells

\section{Hosted file}

Table_02.pdf available at https://authorea.com/users/399241/articles/511801-integratedproduction-of-an-influenza-a-vaccine-candidate-with-mdck-suspension-cells 